\title{
Characterization of the Angular Leaf Spot Resistance Gene Present in Common Bean Cultivar Ouro Negro
}

\author{
Demerson Arruda Sanglard ${ }^{1}$, Carlos Alexandre Gomes Ribeiro ${ }^{1}$, Bruno Pereira Balbi ${ }^{1}$, Klever Márcio Antunes \\ Arruda $^{1}$, Everaldo Gonçalves de Barros ${ }^{1,2}$ \& Maurilio Alves Moreira ${ }^{1,3}$ \\ ${ }^{1}$ Instituto de Biotecnologia Aplicada à Agropecuária (BIOAGRO), Universidade Federal de Viçosa, Viçosa, \\ Brazil \\ ${ }^{2}$ Departamento Biologia Geral, Universidade Federal de Viçosa, Viçosa, Brazil \\ ${ }^{3}$ Departamento Bioquímica e Biologia Molecular, Universidade Federal de Viçosa, Viçosa, Brazil \\ Correspondence: Everaldo Gonçalves de Barros, Instituto de Biotecnologia Aplicada à Agropecuária (BIOAGRO), \\ Universidade Federal de Viçosa, Viçosa, MG, Brazil. Tel: 55-31-3899-2947. E-mail: ebarros@ufv.br
}

Received: September 24, 2012 Accepted: November 7, 2012 Online Published: January 15, 2013

doi:10.5539/jas.v5n2p19

URL: http://dx.doi.org/10.5539/jas.v5n2p19

\begin{abstract}
Angular leaf spot (ALS), incited by the fungus Pseudocercospora griseola, is a major disease affecting common bean. Important resistance sources have been identified and characterized: AND 277, BAT 332, Cornell 49-242, MAR-2, and Mexico 54. P. griseola presents high physiological variability. The control of this kind of pathogen requires continuous evaluation, including monitoring and characterization of pathogenic variability, and eventual germplasm introgression of genes in adapted cultivars. Cultivar Ouro Negro is currently being used as an ALS resistance source in Brazil. This work aimed to characterize the ALS resistance gene present in cultivar Ouro Negro in relation to the other five resistance sources. These cultivars were crossed with 'Ouro Negro' (allelism tests) and with susceptible cv. Rudá (inheritance studies) and their segregation patterns were evaluated. The inheritance studies and the allelism tests indicate that 'Ouro Negro' harbors at least one resistance locus which is distinct from those present in the other resistance sources.
\end{abstract}

Keywords: allelism test, inheritance studies, Phaseolus vulgaris, Pseudocercospora griseola

\section{Introduction}

Angular leaf spot, incited by Pseudocercospora griseola (Sacc.) Crous and Braun, is among the fungal diseases causing great damage to common bean growers (Rava, 2002). ALS occurs essentially in all bean growing regions mainly under mild temperatures and high humidity. These conditions, combined with the use of susceptible cultivars, favor the occurrence of the disease, leading to losses that may reach over $80 \%$ of the production. The high pathogenic variability of $P$. griseola is an obstacle for the development of resistant cultivars (Nietsche et al., 2001; Sartorato, 2006; Sartorato \& Alzate-Marin, 2004; Silva, Souza, Sartorato, \& Freire, 2008).

Pastor-Corrales and Jara (1995) characterized 316 isolates of the pathogen from 11 Latin American and 10 African countries, based on a set of differential cultivars and found that 82 were Andean, 193 Mesoamerican and 41 of unknown origin. Although the isolates have shown considerable variation between and within countries, it was possible to conclude that $P$. griseola and the common bean co-evolved. It was also observed that, in general, Mesoamerican isolates are more virulent than those of Andean origin.

Stable resistance to plant pathogens with high physiological variability requires monitoring of isolates and race characterization in addition to continuous germplasm evaluation and eventual introgression of resistance genes in adapted cultivars (Young \& Kelly, 1996; Iwo, Ittah, \& Osai, 2012). To facilitate this process, and to identify new resistance sources, the inheritance of resistance genes needs to be determined. In addition, allelism tests are required to determine possible relationships among these genes, aiming to orient crosses and possible association (pyramiding) of different resistance genes in the same background.

In Brazil, 'AND 277', 'BAT 332', 'Cornell 49-242', 'MAR-2', and 'Mexico 54' are important ALS resistance sources (Balbi et al., 2009; Nietsche, et al., 2001; Sartorato \& Alzate-Marin, 2004; Silva et al., 2008). The resistance present in these genotypes in crosses with susceptible cultivar Rudá was shown to be monogenic and dominant (Caixeta et al., 2003; Carvalho et al., 1998; Ferreira et al., 2000; Nietsche et al., 2000; Sartorato et al., 
2000). However, using allelism tests with these same cultivars Caixeta et al. (2005) demonstrated that the complexity involving the resistance loci in these sources is greater than previously thought.

Cultivar Ouro Negro (Honduras 35) harbors an ALS resistance gene, provisionally designated Phg-ON, which has been shown to confer a broad resistance spectrum to ALS (Balbi et al., 2009; Sanglard et al., 2009a; Sartorato, 2006). This cultivar presents desirable agronomic and cooking characteristics, high combining ability and has been used in Brazil as an ALS resistance source (Sanglard et al., 2005; Sartorato, 2006). Ouro Negro is also used as an anthracnose and rust resistance source in Brazil. It is resistant to Uromyces appendiculatus races 6, 7, 9, 10, 12, 15, 35, 45, 49, 50, and 59 and to most Colletotrichum lindemuthianum races except for race 65 (Faleiro et al., 2001; Ragagnin et al., 2003). This study aimed to characterize the ALS resistance gene present in cultivar Ouro Negro in relation to the other five ALS resistance sources previously characterized.

\section{Materials and Methods}

\subsection{Genetic Material}

Seeds of the common bean genotypes used in the present study were obtained from: International Center for Tropical Agriculture (CIAT, Cali, Colombia), Germplasm Bank of the Biotechnology Institute - BIOAGRO (UFV, Viçosa, MG, Brazil), USDA (Beltsville, Maryland, USA) and Embrapa Arroz e Feijão (Santo Antônio de Goiás, $\mathrm{GO}$, Brazil).

\subsection{Inheritance Studies and Allelism Tests}

For the inheritance studies, genotypes Ouro Negro, BAT 332, Cornell 49-242, MAR-2 and Mexico 54 were crossed with Rudá (female parent). For the allelism studies, genotypes AND 277, BAT 332, Cornell 49-242, MAR-2 and Mexico 54 were crossed with Ouro Negro (male parent). To ensure that the $F_{1}$ seeds were true hybrids, we analyzed the color, shape, size and brightness of the corresponding $F_{2}$ seeds. In the case of the cross between 'Ouro Negro' and 'Cornell 49-242', which are phenotypically very similar, the $F_{1}$ seeds were submitted to a molecular analysis with marker SF $10_{1050 \mathrm{a}}$ (Corrêa et al., 2000) according to a procedure described by Alzate-Marin et al. (1996). The $\mathrm{F}_{2}$ segregating populations were used in artificial inoculations.

\subsection{Fungal Races and Inoculum Preparation}

The P. griseola isolates (races 31.17, 63.19, 63.23, and 63.39) used in the study were provided by the BIOAGRO/UFV Fungal Collection. These races are the same ones used by Caixeta et al. (2005) in allelism tests. The races showing incompatibility with 'Ouro Negro' and the other ALS resistance sources were used in the allelism tests and in the inheritance studies involving susceptible cultivar Rudá. The inoculum consisted of a spore suspension prepared by scraping the surface of 12-day-old fungal colonies grown according to Sanglard et al. (2009b). For inoculation the suspension was diluted to $2.0 \times 10^{4}$ conidia $/ \mathrm{mL}$.

\subsection{Inoculation and Disease Assessment}

Seeds of each genotype were sown in plastic pots of $2.5 \mathrm{~L}$ containing a mixture of soil and dry manure at a ratio of $4: 1$, and NPK (4-14-8) in a proportion of $5 \mathrm{~kg}$ per $\mathrm{m}^{3}$ of substrate. Twelve plants of each progenitor and all $\mathrm{F}_{2}$ plants were inoculated when they were at the V3 stage (14-16 days old) at a density of four plants per pot. Inoculations were performed on the adaxial and abaxial surfaces of the first trifoliate leaf with the aid of a DeVilbiss atomizer no. 15. After inoculation, the plants were transferred to a mist chamber $\left(20 \pm 1{ }^{\circ} \mathrm{C}\right.$ and relative humidity $>95 \%$ ), where they remained for $48 \mathrm{~h}$, under a 12 -h photoperiod. Then the plants were again transferred to the greenhouse, where they remained until they were evaluated. Disease severity was assessed visually at 18 and 21 days after inoculation using a nine-degree severity scale (Van-Schoonhoven \& Pastor-Corrales, 1987). Plants with grades $\leq 3$ were assumed to be resistant, and those graded 4 or higher, susceptible.

\subsection{Statistical Analysis}

For the statistical analyses the GENES software (Cruz, 2006) was used. Nine phenotypic ratios were considered: 3:1 (one dominant gene), 15:1 (two dominant independent genes), 9:7 (two dominant complementary genes), 13:3 (two epistatic genes, one dominant and one recessive), 63:1 (three independent dominant genes), 57:7 (one dominant and two complementary genes), 27:37 (three dominant complementary genes), 61:3 (two dominant and one recessive gene), 49:15 (one dominant and two recessive genes). The chi-square test was used to indicate the most probable segregation ratio.

\section{Results and Discussion}

P. griseola races 63.23 and 63.39 were chosen to be used in the allelism tests because they were incompatible with 'Ouro Negro' and with the other ALS resistance sources used in the crosses (Table 1). These two races were also used in the inheritance studies (Table 2). 
The segregation ratio of 3:1 obtained in the crosses between susceptible cultivar Rudá and Ouro Negro confirmed that Ouro Negro harbors at least one gene conferring resistance to P. griseola races 63.23 and 63.39 (Table 2). The same conclusion can be inferred from the segregation ratio (3:1) obtained in the crosses Rudá x AND 277, Rudá x BAT 332, and Rudá x MAR-2. In the case of Mexico 54, two resistance genes are involved (segregation ratio of 15:1) (Table 2).

Table 1. Reaction of bean genotypes to different races of Pseudocercospora griseola

\begin{tabular}{lcccc}
\hline \multirow{2}{*}{ Genotypes } & \multicolumn{3}{c}{ Races } \\
\cline { 2 - 5 } & 63.23 & 63.39 & 63.19 & 31.17 \\
\hline AND 277 & ${ }^{\mathrm{a}} \mathrm{R}$ & ${ }^{\mathrm{b}} \mathrm{S}$ & $\mathrm{R}$ & $\mathrm{R}$ \\
BAT 332 & $\mathrm{S}$ & $\mathrm{R}$ & $\mathrm{S}$ & $\mathrm{S}$ \\
Cornell 49-242 & $\mathrm{R}$ & $\mathrm{S}$ & $\mathrm{R}$ & $\mathrm{R}$ \\
MAR-2 & $\mathrm{R}$ & $\mathrm{R}$ & $\mathrm{R}$ & $\mathrm{R}$ \\
Mexico 54 & $\mathrm{R}$ & $\mathrm{R}$ & $\mathrm{R}$ & $\mathrm{R}$ \\
Ouro Negro & $\mathrm{R}$ & $\mathrm{R}$ & $\mathrm{S}$ & $\mathrm{S}$ \\
Rudá & $\mathrm{S}$ & $\mathrm{S}$ & $\mathrm{S}$ & $\mathrm{S}$ \\
\hline
\end{tabular}

${ }^{\mathrm{a}} \mathrm{R}$ : resistant; ${ }^{\mathrm{b}} \mathrm{S}$ : susceptible.

In previous works, cultivar Rudá was crossed with the following resistance sources: AND 277 (Carvalho et al., 1998), MAR-2 (Ferreira et al., 2000), Mexico 54 (Sartorato et al., 2000), Cornell 49-242 (Nietsche et al., 2000) and BAT 332 (Caixeta et al., 2003). The segregation analysis indicated that resistance was monogenic and dominant. However, the use of different crosses and different races showed greater complexity than was previously reported. According to Caixeta et al. (2005) Cornell 49-242 harbors only one dominant gene (Phg-3), Mexico 54 harbors three genes (Phg-2, Phg-5, Phg-6), MAR-2 harbors two genes (Phg-4 and Phg- $5^{2}$, an allelic form of Phg-5), BAT 332 has the allelic form $P h g-6^{2}$, and AND 277 harbors the allelic forms $P h g-2^{2}, P h g-3^{2}$ and $P h g-4^{2}$.

Table 2. Segregation of angular leaf spot resistance genes in common bean $F_{2}$ populations inoculated with Pseudocercospora griseola races 63.23 or 63.39

\begin{tabular}{|c|c|c|c|c|c|c|c|}
\hline \multirow{2}{*}{$F_{2}$ Population } & \multirow{2}{*}{ Race } & \multicolumn{2}{|c|}{$N^{0}$ of $F_{2}$ plants } & \multicolumn{2}{|c|}{ Expected ratio } & \multirow{2}{*}{$\chi^{2}$ value } & \multirow{2}{*}{${ }^{\mathrm{c}} \mathbf{P}(\mathbf{\%})$} \\
\hline & & ${ }^{a} \mathbf{R}$ & ${ }^{\mathrm{D}} \mathbf{S}$ & $\mathbf{R}$ & $\mathbf{S}$ & & \\
\hline Rudá x Ouro Negro & 63.23 & 226 & 71 & 3 & 1 & 0.1898 & 66.3187 \\
\hline Rudá x Ouro Negro & 63.39 & 354 & 111 & 3 & 1 & 0.3161 & 57.3943 \\
\hline${ }^{\mathrm{d}}$ Rudá x AND 277 & 63.23 & 145 & 48 & 3 & 1 & 0.0017 & 96.6850 \\
\hline Rudá x BAT 332 & 63.39 & 396 & 129 & 3 & 1 & 0.0514 & 82.0595 \\
\hline Rudá x Mexico 54 & 63.23 & 376 & 28 & 15 & 1 & 0.3194 & 57.1950 \\
\hline Rudá x Mexico 54 & 63.39 & 355 & 22 & 15 & 1 & 0.1105 & 73.9551 \\
\hline Rudá x MAR-2 & 63.23 & 387 & 125 & 3 & 1 & 0.0937 & 75.9462 \\
\hline${ }^{\mathrm{e}}$ Rudá x MAR-2 & 63.39 & 121 & 37 & 3 & 1 & 0.2109 & 64.6007 \\
\hline Rudá x Cornell 49-242 & 63.23 & 303 & 98 & 3 & 1 & 0.0673 & 79.5262 \\
\hline AND 277 x Ouro Negro & 63.23 & 432 & 25 & 15 & 1 & 0.4739 & 49.1170 \\
\hline BAT 332 x Ouro Negro & 63.39 & 404 & 92 & 13 & 3 & 0.0132 & 90.8413 \\
\hline Mexico 54 x Ouro Negro & 63.23 & 551 & 8 & 63 & 1 & 0.0627 & 80.2239 \\
\hline Mexico 54 x Ouro Negro & 63.39 & 376 & 4 & 63 & 1 & 0.6422 & 42.2889 \\
\hline MAR-2 x Ouro Negro & 63.23 & 415 & 24 & 15 & 1 & 0.4593 & 49.7915 \\
\hline MAR-2 x Ouro Negro & 63.39 & 398 & 28 & 15 & 1 & 0.0757 & 78.3150 \\
\hline Cornell 49-242 x Ouro Negro & 63.23 & 396 & 25 & 15 & 1 & 0.0698 & 79.1579 \\
\hline
\end{tabular}

${ }^{\mathrm{a}} \mathrm{R}$ : resistant; ${ }^{\mathrm{b}} \mathrm{S}$ : susceptible; ${ }^{\mathrm{c}} \mathrm{P}(\%)$ : percent probability; ${ }^{\mathrm{d}}$ data obtained by Carvalho et al. (1998); ${ }^{\mathrm{e}}$ data obtained by Ferreira et al. (2000). 
Based on the assessment depicted in Table 1 race 63.23 was inoculated in four $\mathrm{F}_{2}$ populations for allelism tests (Table 2). For the $F_{2}$ populations AND 277 x Ouro Negro, Cornell 49-242 x Ouro Negro, and MAR-2 x Ouro Negro a typical segregation pattern of two genes (15:1) was obtained, indicating that each of these genotypes contributes with a dominant gene for the resistance reaction. For the population Mexico 54 x Ouro Negro a segregation ratio of 63:1 was obtained, indicating the action of two of the three genes characterized in Mexico 54 for resistance to this race (Caixeta et al., 2005).

Inoculations with race 63.39 produced similar results to those observed with race 63.23 . The $\mathrm{F}_{2}$ populations Mexico 54 x Ouro Negro and MAR-2 x Ouro Negro inoculated with race 63.39 also showed segregation ratios of 63:1 and 15:1, respectively. The $F_{2}$ population BAT $332 \times$ Ouro Negro segregated in a proportion of 13:3, which is typical of an inheritance involving two epistatic genes, one dominant and one recessive. The $\mathrm{F}_{2}$ populations AND 277 x Ouro Negro and Cornell 49-242 x Ouro Negro were not tested with race 63.39 because Cornell 49-242 and AND 277 are susceptible to this race (Table 1). Following the same reasoning the $F_{2}$ population BAT $332 \times$ Ouro Negro was not inoculated with race 63.23 because BAT 332 was susceptible to this race (Table 1).

Our results strongly indicate that Ouro Negro harbors one ALS resistance gene or complex gene locus which confers resistance to both races 63.23 and 63.39. This is supported by the observation that inoculation of $\mathrm{F}_{2}$ population Mexico 54 x Ouro Negro with these two races yielded the same segregation ratio of 63:1. This was also the case for $F_{2}$ population MAR-2 x Ouro Negro (segregation ratio of 15:1) (Table 2). Furthermore, inheritance studies (Rudá $x$ Ouro Negro) involving inoculation by these two races revealed a 3:1 segregation pattern typical of a monogenic dominant inheritance (Table 2). In addition, considering the segregation ratios obtained in all five $\mathrm{F}_{2}$ populations, it can be inferred that at least one ALS resistance locus present in 'Ouro Negro' differs from those present in AND 277, BAT 332, Cornell 49-242, MAR-2, and Mexico 54.

We suggest the 'Ouro Negro' ALS resistance gene is distinct from the other ALS resistance sources characterized so far, and be named Phg-7. This classification would be consistent with the work done by Caixeta et al. (2005).

\section{Acknowledgements}

The authors wish to express their gratitude to the Brazilian Government Agencies CNPq and Fapemig for financial support.

\section{References}

Alzate-Marin, A. L., Baía, G. S., Martins Filho, S., Paula Júnior, T. J. D., Sediyama, C. S., Barros, E. G., \& Moreira, M. A. (1996). Use of RAPD-PCR to identify true hybrid plants from crosses between closely related $\begin{array}{lllll}\text { progenitors. Brazilian Journal of } & \text { Genetics, } & \text { 19, }\end{array}$ http://dx.doi.org/10.1590/S0100-84551996000400016

Balbi, B. P., Sanglard, D. A., Arruda, K. M. A., Costa, M. R., Piovesan, N. D., Barros, E. G., \& Moreira, M. A. (2009). Characterization of Pseudocercospora griseola isolates collected in the state of Minas Gerais, Brazil. Annual Report of the Bean Improvement Cooperative, 52, 56-57.

Caixeta, E. T., Borém, A., Fagundes, S. D. A., Niestche, S., Barros, E. G., \& Moreira, M. A. (2003). Inheritance of angular leaf spot resistance in common bean line BAT 332 and identification of RAPD markers linked to the resistance gene. Euphytica, 134(3), 297-303. http://dx.doi.org/10.1023/B:EUPH.0000004948.41083.1f

Caixeta, E. T., Borém, A., Alzate-Marin, A., Fagundes, S., Silva, M., Barros, E. G., \& Moreira, M. A. (2005). Allelic relationships for genes that confer resistance to angular leaf spot in common bean. Euphytica, 145(3), 237-245. http://dx.doi.org/10.1007/s10681-005-1258-3

Carvalho, G. A., Paula Júnior, T. J. D., Alzate-Marin, A. L., Niestche, S., Barros, E. G., \& Moreira, M. A. (1998). Herança da resistência da linhagem AND-277 de feijoeiro-comum à raça 63-23 de Phaeoisariopsis griseola $\mathrm{e}$ identificação de marcador RAPD ligado ao gene de resistência. Fitopatologia Brasileira, 23, 482-485.

Corrêa, R. X., Costa, M. R., Good-God, P. I., Ragagnin, V. A., Faleiro, F. G., Moreira, M. A., \& Barros, E. G. (2000). Sequence characterized amplified regions linked to rust resistance genes in the common bean. Crop Science, 40(3), 804-807. http://dx.doi.org/10.2135/cropsci2000.403804x

Cruz, C. D. (2006). Programa Genes-Estatística experimental e matrizes. Editora Universidade Federal de Viçosa.

Faleiro, F. G., Nietsche, S., Ragagnin, V. A., Borém, A., Moreira, M. A., \& Barros, E. G. (2001). Resistência de cultivares de feijoeiro-comum à ferrugem e à mancha-angular em condições de casa de vegetação. Fitopatologia Brasileira, 26, 86-89. http://dx.doi.org/10.1590/S0100-41582001000100015 
Ferreira, C. F., Borém, A., Carvalho, G. A., Nietsche, S., Paula, T. J., Barros, E. G., \& Moreira, M. A. (2000). Inheritance of angular leaf spot resistance in common bean and identification of a RAPD marker linked to a resistance gene. Crop Science, 40(4), 1130-1133. http://dx.doi.org/10.2135/cropsci2000.4041130x

Iwo, G. A., Ittah, M. A., \& Osai, E. O. (2012). Sources and genetics of resistance to soybean rust Phakopsora pachyrhizi (H. Sydow \& Sydow) in Nigeria. Journal of Agricultural Science, 4(10), 1-6. http://dx.doi.org/10.5539/jas.v4n10p1

Nietsche, S., Borém, A., Carvalho, G. A., Rocha, R. C., Paula Júnior, T. J., Barros, E. G., \& Moreira, M. A. (2000). RAPD and SCAR markers linked to a gene conferring resistance to angular leaf spot in common bean. Journal of Phytopathology, 148(2), 117-121. http://dx.doi.org/10.1046/j.1439-0434.2000.00479.x

Nietsche, S., Borém, A., Carvalhos, G. A., Paula Júnor, T. J., Ferreira, C. F., Barros, E. G., \& Moreira, M. A. (2001). Genetic diversity of Phaeoisariopsis griseola in the State of Minas Gerais, Brazil. Euphytica, 117(1), 77-84. http://dx.doi.org/10.1023/a:1004096421990

Pastor-Corrales, M. A., \& Jara, C. E. (1995). La evolución de Phaeoisariopsis griseola con el frijol común en América Latina. Fitopatologia Colombiana, 19, 15-24.

Ragagnin, V. A., Alzate-Marin, A. L., Souza, T. L. P. O., Arruda, K. M. A., Moreira, M. A., \& Barros, E. G. (2003) Avaliação da resistência de isolinhas de feijoeiro ao Colletotrichum lindemuthianum, Uromyces appendiculatus e Phaeoisariopsis griseola. Fitopatologia Brasileira, 28, 591-596. http://dx.doi.org/10.1590/S0100-41582003000600002

Rava, C. A. (2002). Influência de fungicidas no controle da antracnose e da mancha-angular em feijoeiro comum. Summa Phytopathologica, 28, 65-69.

Sanglard, D. A., Balbi, B. P., Barros, E. G., \& Moreira, M. A. (2009b). An efficient protocol for isolation, sporulation and maintenance of Pseudocercospora griseola. Annual Report of the Bean Improvement Cooperative, 52, 62-63.

Sanglard, D. A., Ribeiro, C. A. G., Balbi, B. P., Barros, E. G., \& Moreira, M. A. (2009a). Reaction of common bean cultivars and elite lines to isolates of Pseudocercospora griseola. Annual Report of the Bean Improvement Cooperative, 52, 64-65.

Sanglard, D. A., Souza, T. L. P. O., Sousa, C. S., Ragagnin, V. A., Barros, E. G., \& Moreira, M. A. (2005). Molecular marker assisted backcrossing for developing lines with cv. Pérola genetic background, resistant to rust, anthracnose and angular leaf spot. Annual Report of the Bean Improvement Cooperative, 48, 84-85.

Sartorato, A. (2006). Novas fontes de resistência do feijoeiro comum à mancha-angular. Fitopatologia Brasileira, 31, 192-194. http://dx.doi.org/10.1590/S0100-41582006000200012

Sartorato, A., \& Alzate-Marin, A. L. (2004). Analysis of the pathogenic variability of Phaeoisariopsis griseola in Brazil. Annual Report of the Bean Improvement Cooperative, 47, 235-237.

Sartorato, A., Niestche, S., Barros, E. G., \& Moreira, M. A. (2000). RAPD and SCAR markers linked to resistance gene to angular leaf spot in common beans. Fitopatologia Brasileira, 25, 637-642.

Silva, K. J. D., De Souza, E. A., Sartorato, A., \& Freire, C. N. D. (2008). Pathogenic variability of isolates of Pseudocercospora griseola, the cause of common bean angular leaf spot, and its implications for resistance breeding. Journal of Phytopathology, 156(10), 602-606. http://dx.doi.org/10.1111/j.1439-0434.2008.01413.x

Van-Schoonhoven, A., \& Pastor-Corrales, M. A. (1987). Sistema estándar para la evaluación de germoplasma de frijol. Cali: Ciat.

Young, R. A., \& Kelly, J. D. (1996). Characterization of the genetic resistance to Colletotrichum lindemuthianum in common bean differential cultivars. Plant Disease, 80, 650-654. http://dx.doi.org/10.1094/PD-80-0650 